\title{
Motivation of Farmers in Cabbage Farming in Central Java Indonesia
}

\author{
Lestari Rahayu \\ Department of Agribusiness \\ Universitas Muhammdiyah Yogyakarta \\ Yogyakarta, Indonesia \\ lestari@umy.ac.id
}

\author{
Indardi \\ Department of Agribusiness \\ Universitas Muhammdiyah Yogyakarta \\ Yogyakarta, Indonesia \\ indardi@umy.ac.id
}

\author{
Nia Apina \\ Department of Agribusiness \\ Universitas Muhammdiyah Yogyakarta \\ Yogyakarta, Indonesia \\ nia.apina@gmail.com
}

\begin{abstract}
Increased cabbage production in Central Java is not followed by an increase in cabbage prices at the farm level. Farmers have cabbage farming motivation even though cabbage prices tend to fall and are not stable. This research aimed to describe the motivation of farmers in cabbage farming and to describe the relationship between influencing factors with a motivation of farmers in cabbage farming. This research was designed with descriptive analysis method. Central Java was chosen as the research location because it has a high cabbage production and is a recommended area for cabbage exports. The data analysis techniques were descriptive analysis and Rank Spearman Correlation. The result of the analysis showed that the motivation of farmers in cabbage farming is at the moderate level. Farmers have the need for existence at a moderate level, the need for relatedness at the highest level, and the need for growth at a low level. Age, formal education, training, counseling, farming experience, income and availability of capital have a significant relationship with the motivation of farmers in cabbage farming. It is necessary to provide special training and counseling to young farmers to increase the motivation of cabbage farmers.
\end{abstract}

Keywords- cabbage, existence, growth, motivation, relatedness

\section{INTRODUCTION}

Vegetables are an essential commodity in everyday life. Vegetables provide health benefits other than fruits. One of the vegetables favored by the community is cabbage. Cabbage is an essential commodity that provides health benefits for the body. All people, from the lower classes to the upper classes, consume cabbage. Based on data on vegetable production in Indonesia in 2014 , cabbage production reached $1,435,833$ tons or $12.05 \%$ of the total vegetable production in Indonesia (Ministry of Director General of Horticulture 2015). Cabbage became one of the vegetables that contributed the most to the total vegetable production in 2014. Cabbage is produced based on market demand both in the domestic and foreign markets. The consumption of domestic cabbage in the form of fresh and processed Indonesian cabbage in one year is estimated at an average of 600,000 tons [1]

In Indonesia the production of cabbage takes place in various regions. According to the Ministry of Director General of Horticulture (2015), Java Island produces the most cabbage compared to other islands. Central Java is the largest cabbage production center with a total production of 358,343 tons with a percentage of $24.96 \%$ of all the production in Indonesia. Each region has different productions, depending on the environmental conditions and farmers' cabbage farming practices. According to BPS (2014), cabbage production in Central Java experienced an increase since 2009 to 2014. Central Java became the center of cabbage production suggested by the Central Government to export the produced cabbage. However, bumper cabbage production often makes farmerssuffer losses.

Moreover, during harvest time, the price of cabbage can meagerly reach IDR600/kg. The price of cabbage in Central Java can be said to be unstable. In a season of plenty, sometimes the production cost does not return. However, on the contrary, during a season of famine, the price is costly reaching IDR 4,500/kg [2]. As reported by [2], many cabbage farmers in Central Java said the price of cabbage fell from IDR $2,000 / \mathrm{kg}$ to IDR $600 / \mathrm{kg}$. Low cabbage prices in Central Java still occur in 2018 with a price range of IDR $1,000-1,500 / \mathrm{kg}$ because cabbage farmers harvest simultaneously. Of course, this low price is not as expected and causes cabbage farmers to suffer losses [3].

An increase in cabbage production is expected to improve the welfare of cabbage farmers lives. Improved welfare of cabbage farmers can be seen from farmers' income from cabbage farming. However, sometimes the quality of cabbage produced by farmers is not as expected, resulting in a cabbage price that is falling. Besides, non-optimal marketing may also lead to a change in the market price of cabbage. As a result, the income earned by cabbage farmers is not as desired. Farmers tend to receive a low price of cabbage, but they still continue cabbage farming. In fact, in cabbage farming, farmers certainly have some underlying motivations. Referring to the ERG motivation theory (Existence, Relatedness, Growth), in farming, farmers usually have three needs, namely the need for existence, relatedness, and growth. This study aimed to describe the motivation of farmers in cabbage farming, includeng Any factors related to the motivation, both internal and external factors.

\section{METHODS}

The method used in this research was a descriptive analysis method. The number of samples to be selected was determined using the Slovin formula, so 65 respondents were selected among 175 populations. The sampling was carried out by proportional random sampling. To find out the motivation of farmers in cabbage farming, scoring techniques were used. The scoring was classified into three categories which were measured using interval formulas, as follows: [4]

Motivation measurement was done by calculating the average score of each statement, then the scores of each statement were summed up to find out the indicator score from each motivation (Table 1). The score of each motivation in the 
forms of existence, relatedness and growth was measured by calculating the total score of all the motivational indicators (Table 2) The overall level of motivation was also calculated by summing um the scores of all the motivations. The overall measurement of motivation categories (table 3)

Table 1. Individual Categories for Motivation Indicators

\begin{tabular}{|c|c|c|c|c|}
\hline \multirow{2}{*}{ Indicators } & \multirow{2}{*}{$\begin{array}{c}\text { Range } \\
\text { of } \\
\text { Scores }\end{array}$} & \multicolumn{3}{|c|}{ Categories } \\
\hline & & Low & Moderate & High \\
\hline \multicolumn{5}{|c|}{ Existence } \\
\hline $\begin{array}{l}\text { Motivation to meet the } \\
\text { family needs for food }\end{array}$ & $2-6$ & $2-3.33$ & $3.34-4.67$ & $4.68-6$ \\
\hline $\begin{array}{l}\text { Motivation to meet } \\
\text { non-food primary } \\
\text { needs }\end{array}$ & $4-12$ & $4-6.66$ & $6.67-9.33$ & $9.34-12$ \\
\hline $\begin{array}{l}\text { Motivation to meet the } \\
\text { needs for school tuition } \\
\text { fees }\end{array}$ & $4-12$ & $4-6.66$ & $6.67-9.33$ & $9.34-12$ \\
\hline $\begin{array}{l}\text { Motivation to meet the } \\
\text { needs for security }\end{array}$ & $2-6$ & $2-3.33$ & $3.34-4.67$ & $4.68-6$ \\
\hline $\begin{array}{l}\text { Motivation to maintain } \\
\text { family income }\end{array}$ & $2-6$ & $2-3.33$ & $3.34-4.67$ & $4.68-6$ \\
\hline \multicolumn{5}{|c|}{ Relatedness } \\
\hline $\begin{array}{l}\text { Motivation to interact } \\
\text { with others }\end{array}$ & $3-9$ & $3-4.99$ & $5-6.99$ & $7-9$ \\
\hline $\begin{array}{l}\text { Motivation to expand } \\
\text { social relations }\end{array}$ & $2-6$ & $2-3.33$ & $3.34-4.67$ & $4.68-6$ \\
\hline $\begin{array}{l}\text { Motivation to } \\
\text { cooperate with others }\end{array}$ & $2-6$ & $2-3.33$ & $3.34-4.67$ & $4.68-6$ \\
\hline $\begin{array}{l}\text { Motivation } \\
\text { strengthen } \\
\text { relations }\end{array}$ & $2-6$ & $2-3.33$ & $3.34-4.67$ & $4.68-6$ \\
\hline \multicolumn{5}{|c|}{ Growth } \\
\hline $\begin{array}{l}\text { Motivation to meet } \\
\text { tertiary needs }\end{array}$ & $2-6$ & $2-3.33$ & $3.34-4.67$ & $4.68-6$ \\
\hline $\begin{array}{l}\text { Motivation to increase } \\
\text { knowledge of cabbage } \\
\text { farming }\end{array}$ & $2-6$ & $2-3.33$ & $3.34-4.67$ & $4.68-6$ \\
\hline $\begin{array}{l}\text { Motivation to improve } \\
\text { cabbage farming skills }\end{array}$ & $2-6$ & $2-3.33$ & $3.34-4.67$ & $4.68-6$ \\
\hline $\begin{array}{l}\text { Motivation to be } \\
\text { respected by others }\end{array}$ & $2-6$ & $2-3.33$ & $3.34-4.67$ & $4.68-6$ \\
\hline
\end{tabular}

Table 2. Category for Each Motivation Variable

\begin{tabular}{cccc}
\hline \multirow{2}{*}{ Indicator } & \multicolumn{3}{c}{ Category } \\
\cline { 2 - 4 } & Low & Moderate & High \\
\hline Existence & $14.00-23.33$ & $23.34-32.66$ & $32.67-42.00$ \\
Relatedness & $9.00-14.99$ & $15.00-20.99$ & $21.00-27.00$ \\
Growth & $8.00-13.32$ & $13.33-18.65$ & $18.66-24.00$ \\
\hline
\end{tabular}

Table 3. Overall Motivation Categories

\begin{tabular}{lc}
\hline Total Score & Category \\
\hline $31-51.66$ & Low \\
$51.67-72.33$ & Moderate \\
$72.34-93$ & High \\
\hline
\end{tabular}

Spearman's Rank Correlation Coefficient analysis was used to determine the relationship of factors that influenced the motivations of farmers in cabbage farming, with the following formula:

$$
r s=1-\frac{6 \Sigma d^{2}}{n\left(n^{2}-1\right)}
$$

Description:

rs : Spearman's Rank Coefficient

d : Difference in rank between variables

n : Number of samples

\section{RESULTS AND DISCUSSION}

Loan capital or an institution with an agreement will have to be repaid at a predetermined time. However, farmers prefer to use their own capital from family savings. In addition, the institution that provides loan capital is located far from the respondents' area. Marketing. As many as $72.31 \%$ of the respondents said that market access for Motivation of farmers in cabbage farming

Farmer motivations were divided into three, namely the need for existence $(\mathrm{E})$, the need for relatedness $(\mathrm{R})$ and the need for growth $(\mathrm{G})$.

Table 4. Average Score and Categories of Farmers' Motivations in Cabbage Farming

\begin{tabular}{cccc}
\hline Variable & $\begin{array}{c}\text { Score } \\
\text { range }\end{array}$ & $\begin{array}{c}\text { Total } \\
\text { Score }\end{array}$ & Category \\
\hline Need for existence & $14-42$ & 28.37 & Average \\
Need for Relatedness & $9-27$ & 22.65 & High \\
Needs for Growth & $8-24$ & 12.88 & Low \\
\hline Motivation & $\mathbf{3 1 - 9 3}$ & $\mathbf{6 3 . 9 0}$ & Moderate \\
\hline
\end{tabular}

Existence Need. The need for existence is a need that encourages farmers to meet their basic needs such as food, clothing and shelter as well as security, manifested in the form of savings. In fact, in cabbage farming, the income earned by farmers is mostly used to meet their primary needs, secondary needs and education for children. On the other hand, a need for security is among those in the last ranks for farmers to fulfill. According to farmers, investment is conditional. This means that if they already meet all their family needs, then they could meet the needs for investment or security. These respondents believed that the needs for food are a priority. No matter how small the income earned by farmers from cabbage farming, firstly it will be used to meet the food needs or family consumption. However, a research by [5] revealed different results that the existence needs are included in the high category. The respondents involved in rice farming had high expectations to meet their physiological and security needs manifested in the form of food availability for the next months, by storing rice rather than selling it.

Relatedness Needs. A high level of motivation regarding the needs for relatedness is because farmers need other people to interact and communicate with, in order to develop their farms. Basically, relatedness is needed by all people as social beings, including farmers. Interaction and communication that occur among cabbage farmers with fellow cabbage farmers or agricultural extension agents aim to work together and meet their social needs. A different research in Boyolali showed that relatedness needs were included in the high category. The respondents assumed that rice farming can have a positive social impact, namely strengthening the brotherhood among farmers, where they feel recognized and safe to be a part of a community or group [5].

Growth Needs. The need for growth is a need that encourages farmers to develop their potential to become more productive, which is beneficial to themselves and the environment. Growth needs are measured by four indicators (Table 6). A low motivation to meet the growth needs might be because in farmers' minds, these needs are additional needs, especially in 
terms of motivation to meet tertiary needs and motivation to be respected. Earning uncertain income is the reason for farmers to focus more on their basic needs rather than their growth needs, which are considered to be quite difficult to achieve; one of them is the motivation to meet tertiary needs for families. A low motivation for growth needs was also found in Boyolali because the respondents wanted to develop farming, both in terms of their creativity and productivity or the environment but they had lack of education both formal and non-formal education, lack of infrastructure and facilities, whether or not farmer groups are active in various hamlets, at least inviting farmers to attend counseling and training [5]

Table 5. Relationship between Internal Factors and Farmers' Motivation

\begin{tabular}{|c|c|c|c|c|c|}
\hline \multicolumn{2}{|c|}{ Criteria } & $\begin{array}{c}\text { Existenc } \\
\text { e }\end{array}$ & $\begin{array}{l}\text { Relatednes } \\
\text { s }\end{array}$ & $\begin{array}{c}\text { Growt } \\
\text { h }\end{array}$ & $\begin{array}{c}\text { Motivatio } \\
\mathbf{n}\end{array}$ \\
\hline \multirow[t]{2}{*}{ Age } & R's & $-0.784 * *$ & $-0.405 * *$ & $-0.294 *$ & $-0.658 * *$ \\
\hline & Sig. & 0.000 & 0.001 & 0.017 & 0.000 \\
\hline \multirow{2}{*}{$\begin{array}{l}\text { Formal } \\
\text { Education }\end{array}$} & R's & $* * 0.404$ & $* * 0.479$ & 0.583 & $0.546 * *$ \\
\hline & Sig. & 0.001 & 0.000 & $\begin{array}{r}* * \\
0.000\end{array}$ & 0.000 \\
\hline \multirow[t]{2}{*}{ Training } & R's & 0.221 & $0.601 * *$ & $\begin{array}{r}0.571 \\
* *\end{array}$ & $0.462 * *$ \\
\hline & Sigh & 0.077 & 0.000 & 0.000 & \\
\hline \multirow[t]{2}{*}{ Counseling } & R's & $0.266 *$ & $0.295 *$ & $\begin{array}{r}0.574 \\
* *\end{array}$ & $0.422 * *$ \\
\hline & Sig. & 0.032 & 0.017 & 0.000 & 0.000 \\
\hline \multirow{2}{*}{$\begin{array}{l}\text { Farming } \\
\text { Experience }\end{array}$} & R's & -0.718 & $-0.363 * *$ & -0.414 & $-0.684 * *$ \\
\hline & Sig. & & 0.003 & $\begin{array}{r}* * \\
0.001\end{array}$ & 0.000 \\
\hline \multirow[t]{2}{*}{ Land area } & $R^{\prime} s$ & 0.101 & 0.546 & - & 0.076 \\
\hline & Sig. & 0.699 & $\begin{array}{l}0.040 \\
0.990\end{array}$ & $\begin{array}{c}0.002 \\
0.423\end{array}$ & -0.049 \\
\hline \multirow[t]{2}{*}{ Land Status } & R's & 0.9420 .4 & 0009 & 0.169 & 0.090 \\
\hline & Sig & 0.963 & 0.009 & 0.179 & 0.006 \\
\hline \multirow[t]{2}{*}{ Income } & $\mathrm{R}^{\prime} \mathrm{s}$ & 0.182 & 0.136 & $0.293 *$ & $0.302 *$ \\
\hline & Sig. & 0.146 & 0.282 & 0.018 & 0.015 \\
\hline
\end{tabular}

* Significance of $5 \%$

** Significance of $1 \%$

Internal and external factors. Factors that influenced the motivation of farmers in choosing cabbage farming were divided into two, namely internal and external factors. The internal factors were age, formal education, non-formal education, income, farming experience, land area and land status. The distribution of the respondents' internal factors is shown in Table 8.

Age. The respondents' age was still classified as productive, but the physical ability of farmers already started to decline. As a result, in their cabbage farming, they could no longer work optimally. Similarly, a research of [6] showed that most of the respondents were relatively young and productive, i.e. in the age range of 31-50 years.

Formal education. A low level of education made it difficult for farmers to accept new innovations, so they still used manual methods. A similar study in Sukoharjo showed that the respondents' low level of education was inseparable from the past i.e. paying little attention to education. In addition, tuition fees are an obstacle for farmers to pursue higher education [7].

Extension. Not many farmers attend counseling. An extension schedule that does not meet the farmers' free time became the main reason why farmers did not attend the extension activities.

Training. In solving their farming problems, they used the same solution as the first time they attempted because they have lack of training. A study from [8] revealed that training has a lot of contribution for farmers to carry out their farming because training helps farmers understand and determine the applications to be used and provides useful farming information.

Income. Low income due to the cultivation of cabbage requires capital for high production facilities but is not offset by rising prices and production. The results of another research showed that the income of sunflower farmers was in the medium category which was between $80,000-107,000$ taka / year or around IDR 15,475,256-17,615,451 / year because farmers used their own land for the farming. [7]

Farming Experience. The average cabbage farmers had experience in farming because the average cabbage farmers were old and had been involved in cabbage farming for a long time. A different result was revealed by [8], showing that most of the farmers' experience was in the low category, which was 2-12 years Because these farmers only succeeded their parents, so they only got their experience by learning from their parents' experiences.

Land area. A medium-sized land area makes farmers get low yields. The results of this study are in line with that of [9] that the respondents had to be able to maximize the productivity of their chili plants in order to meet market demand and the livelihood needs of the farmers themselves. According to [10], farmers with limited land tenure must be able to utilize their land intensively, to provide optimal results in order to increase their income.

Land Status. The status of self-owned land certainly provides more freedom for farmers in making decisions to use their land, starting from the selection of commodities until the use of production facilities. In line with a research by [11], the majority of farmers own their own land, whether the land is their own or given by their parents. The status of self-owned land can reduce farming cost in terms of land rental cost, so the production is expected to increase.

External factors were measured by the availability of capital, marketing and farm risk, suitability of land potential and suitability of local culture. The description of the external factors that influenced the motivation of farmers can be seen in Table 9.

Capital Availability. Based on Table 9, both government assistance and facilitation of farmer groups have not been distributed equally to the respondent farmers. A research by [12] showed the same results, that the availability of capital for farmers originating from outside is only non-bank cabbage commodities is easy to reach at a low cost. The existence of a market that is close to the farmland of the respondent farmers made it easier for them to sell their farming products. In selling their crops, $67.69 \%$ of farmers sold their crops through middlemen. Middlemen usually visited farmers a few days before harvest. The ease of selling these crops certainly benefited farmers because they could save money in terms of 
harvesting and marketing costs. In cabbage pricing, most farmers were involved in the pricing of cabbage with middlemen. The prices usually referred to the local market price, meaning that during harvest time, cabbage tended to have a low price. Regarding the payment system, as many as $83.08 \%$ of the respondent farmers preferred cash system because they wanted to see how much income they got from cabbage farming.

Farming Risk. Pests and diseases attack cabbage plants every time farmers cultivate cabbage. Farmers consider this as normal because the pests attacking cabbage plants are easy to handle. This research was related to the risk of chrysanthemum flower farming. The results showed that the risk of pests and diseases of chrysanthemum flower farming was in the medium category, meaning that these need intensive handling on a stock basis. The intensive handling in this case is the treatment of plants in the form of observing or checking the condition of the plants every day to find out and monitor the condition of disease-prone plants.

Land Suitability Potential. As many as $70.76 \%$ of the respondents said that, in cultivating cabbage, they used both organic and inorganic fertilizers. This is because the land for cabbage farming included dry land. The water available for farming was taken from the river channeled to their fields using an irrigation system. Fortunately, water in this region is always available in accordance with the needs of farming even in the dry season. A research by [13] showed that there was abundant water in Minggir Subdistrict area for Mendong farming, but the irrigation channel was still centralized in one area and the area never experienced drought despite the dry season.

The suitability of local culture for cabbage farming fell under the appropriate category because the cabbage farming has long existed and passed down from generation to generation. This is evident from the fact that even though the price of cabbage tended to fall, these farmers were still willing to cultivate cabbage. This result is in line as that of a research by [13] that the suitability level of Mendong plants with the local culture was high because the farmers considered Mendong plants to be ancestral heritage that had to be preserved. This is evident from the fact that even though the land area reduced and the price of mendong fell, the farmers continued to cultivate it.

\section{Relationship between Factors Affecting with Farmer's Motivation}

Factors that influence the motivation of farmers consist of internal factors and external factors. The results of the analysis of the relationship between both the internal and external factors that influenced the farmers' motivation can be seen in Table 10 .

Age. There is a relationship between age and motivation. There was a negative relationship with a correlation value of 0.658. More motivation of the young farmers in cabbage farming was to provide welfare for their family members. In addition, the knowledge that these young farmers had and being active in group discussions facilitated them in cabbage farming. In contrast to the results of a study of [14] that the older the farmers, the higher the desire to meet the economic needs by cultivating gambir plants. The farmers' motivation in planting gambir was influenced by their life experience seen from the age.

Formal education. There was a significant and positive relationship between formal education and the farmers' motivation. Formal education will make farmers become more advanced and open-minded in accepting the breakthrough of modern agricultural technology that facilitate the development of farming. This is in accordance with a research of [14] which revealed that highly educated farmers are able to think more forward and think of solutions to overcome any farming problems, so they can continue farming.

Training. There is a relationship between training and farmers' motivation. There was a positive or unidirectional correlation with a correlation coefficient value of 0.462 . The number of trainings attended could improve the farming skills or expertise of farmers, thus resulting in a higher motivation in farming. The farmers 'activities such as counseling and training could improve these farmers' knowledge and skills. The more the number of counselings and trainings attended, the faster the process of applying farming innovations so that farmers are able to adopt agricultural innovations.

Counseling. The extension variable had a significant and positive relationship with the farmers' motivation of farmers with a correlation coefficient value of 0.422 . Farmers with higher education will have more knowledge about cabbage farming-related matters. This will make it easier for farmers to solve farming problems they encounter, thus increasing the motivation to cultivate cabbage. Extension activities according to [11] are one of the factors that can influence the motivation of community forest farmers because counseling includes activities that can change farmers' behavior, changes in target behavior in utilizing odor innovation. Therefore, farmers' participation in extension activities could increase the level of motivation of community forest farmers.

Income. There was a significant and positive relationship between income and motivation of farmers. Farmers with higher income will have a great desire to expand their farming, so the motivation of farmers in cabbage farming increases. According to [15], farmers with higher income levels will have a greater chance of choosing crops than farmers with low income levels. Farmers with low incomes are not willing to take risks because of limited capital.

Land area. There was no relationship between land area and the motivation of farmers. This is evident from the fact that farmers with narrow or wide land area can still do cabbage farming. In addition, the land area does not always represent high farm yields. These results are in accordance with a research of [16] which mentioned that a vast area of arable land does not always lead to a high level of farmers' motivation in attending extension activities because some farmers with a large area of land feel hesitant to tak risks by applying technology.

Land Status. Overall, there is no relationship between land status and motivation. Most of the farmers in the research locations cultivated cabbage to meet their family needs and 
most of them selected cabbage farming, so that each of themhad the motivation to cultivate different cabbage.

Capital Availability. There was significant and positive relationship between capital availability and farmers' motivation. Without adequate capital, it is difficult for farmers to develop their farms to achieve optimal production and maximize profits [15]. The availability of capital in accordance with farmers' needs for farming will makes them feel more enthusiastic in performing various works, starting from preparation, cultivation to post-harvest. The availability of capital assistance provided by the government and farmer groups helps farmers in continuing their farming.

Marketing. There was no significant relationship between marketing and the farmers' motivation because the significance value was 0.515 . Marketing became a common problem for the cabbage farmers in the study locations. Marketing is not always easy, making farmers must always think of solutions so that they are able to sell their crops even though sometimes it does not cover the costs incurred.

Farming Risk. There was no significant relationship between farming risk and the farmers' motivation. In farming activities, farmers always encounter a risk situation of which the levels depend on the courage of farmers in risk taking [16]. This means that farmers already know the risks to take but their motivation to cultivate cabbage does not change. The risks faced by the cabbage farmers in the research locations were in the form of pests and diseases attacks that may lead to crop failure.

Land Suitability Potential. Overall, there was no relationship between land suitability potential and the motivation of farmers. This means that the potential of land for farming did not affect the farmers' motivation in cabbage farming. Different research results were shown by [14] that there is a significant relationship between land suitability potential and economic motivation because land overgrown with shrubs and barren land can be grown with Gambier plants well and well. As a result, farmers do not need to incur additional costs for fertilizer and pesticides because Gambier plants are resistant to pests and diseases.

Local Culture Suitability. There was no significant relationship between the suitability of local culture and the motivation of farmers. Th cabbage farming in the study locations was actually suitable with the local culture. These farmers carried out farming from generations to generations, but young farmers had various reasons in addition to cultural factors, such as suitable climate and the ease in cabbage cultivation. Different results were shown by [15] that there is a significant relationship between the level of suitability of local culture and motivation due to reduced land conditions. This makes farmers cultivate gambir plants, in addition to the reason that it is suitable to grow gambir plants on the land of the surrounding community.

\section{CONCLUSION}

Overall, the motivation of farmers in cabbage farming is in the moderate category. In detail, the need for existence is in the moderate category, the need for relatedness is in the high category, and the need for growth falls into the low category.
The factors related to the motivation of farmers in cabbage farming are internal and external factors. The factors that have a significant and positive relationship with the motivation of farmers in cabbage farming are formal education, training, counseling, income and capital availability, while the factors that have a significant and negative relationship with farmers' motivation in cabbage farming are age and farming experience. The factors of land area, land status, marketing, farming risk, land suitability potential and suitability of local culture do not have a significant relationship with the motivation of farmers in cabbage farming.

Age is negatively correlated with the motivation of cabbage farmers, meaning that young farmers who have a high farming motivation. Therefore, it is better to recruit young farmers in the farmer group members to increase motivation in cabbage farming. Non-formal education, such as training and counseling, is very important for farmers to increase their knowledge and skills related to cabbage farming, especially farmers with a low level of formal education. We recommend that the frequency of training and counseling be improved. Besides, it is better to adjustthe trainings and extension materials to the problems faced by cabbage farmers in Central Java. In addition, young farmers need special trainings and counselings to increase their motivation in cabbage farming.

Farmer groups need to take care of legal entities to get potential benefits from it, so that members of farmer group can respond to export opportunities suggested by the Central Government and can motivate young farmers to join the export opportunity. This is expected to increase the motivation of cabbage farmers, especially in terms of their needs for growth.

\section{REFERENCES}

[1] Sunarjono, Hendro. Bertanam 30 Jenis Sayur. Penebar Swadaya, Bandung. 2010

[2] Kompas. 1 Februari 2013. Larangan Impor Stabilkan Harga. Online) http://www.bisniskeuangan.kompas.com diakses 8 Maret 2017.

[3] BPS Kabupaten Tegal. Potret Usaha Pertanian Kabupaten Tegal Menurut Subsektor (Hasil Pencacahan Lengkap Sensus Pertanian 2013 dan Survei Pendapatan Rumah Tangga Usaha Pertanian 2013). BPS Kabupaten Tegal, Tegal. 2014

[4] Kementerian Pertanian Direktorat Jenderal Hortikultura.Statistik Produksi Hortikultura Tahun 2014. Dirjen Hortikultura, Jakarta. 2015

[5] Dewi Marlinda M, Bekti Wahyu U, dan Hanifah Ihsaniyati. . Motivasi Petani Berusahatani Padi (Kasus Di Desa Gunung Kecamatan Semo Kabupaten Boyolali). AGRISTA. 4 (3): 104-114. 2016

[6] Nisa, Naning K. Motivasi Petani dalam Menananm Komoditas Pada Daerah Lumbung Padi di Kabupaten Gresik. Swara Bhumi. 3 (3): 8090. 2015

[7] Primadesi, Febriana. Motivasi Petani dalam Budidaya Tanaman Buah Naga (Hylocereus Sp.) di Kecamatan Bendosari Kabupaten Sukoharjo. Fakultas Pertanian Universitas Sebelas Maret. Surakarta. 2010

[8] Badhan, A., Md. Golam, R. A., and A. T. M. S., Haque. Farmer's Level Motivation on Sunflower Cultivation in a Rice Based Cropping Pattern of Pattern of Patuakhali District. Asian Journal of Agricultural Extension, Economics \& Sociology. 18 (2): 1-11.2017

[9] Widiartha, I. G. W., I Gede, S. A. P., dan Ida, A. L. D. Motivasi Anggota Kelompok Tani dalam Membudidayakan Tanaman Cabai (Kasus pada Kelompok Tani Catu Amerta Sari, Banjar Pura, Desa Sebudi, Kecamatan Selat, Kabupaten Karangasem). Agribisnis dan Agrowisata. 6 (3): 368-377.2017

[10] Restutiningsih, N.L.P., I. K. S. Diarta., I. W. Sudarta. . Motivasi Petani 
dalam Berusahatani Hortikultura di Desa Wisata Candikuning Kecamatan Baturiti Kabupaten Tabanan. E-Jurnal Agribisnis dan Agrowisata. 5 (1). 2016

[11] Astuti, R. P. Motivasi Petani dalam Usahatani Padi Oganik di Kecamatan Pandak Kabupaten Bantul. Skripsi. Fakultas Petanian Universitas Muhammadiyah Yogyakarta, Yogyakarta. 2011

[12] Dewandini, Sri Kuning R. Motivasi Petani dalam Budidaya Tanaman Mendong (Fimbristylis globulosa) Di Kecamatan Minggir Kabupaten Sleman. Skripsi. Fakultas Pertanian Universitas Sebelas Maret. Surakarta. 2010

[13] Nurdina, I.F., Asihing, K. Rudi, H. Motivasi Petani dalam Mengelola Hutan Rakyat di Desa Sukoharjo 1 Kecamatan Sukoharjo Kabupaten Pringsewu. Jurnal Sylva Lestari. 3 (3): 51-62. 2015

[14] Firman RL; Masrizal; dan Abusari, Marbun. Motivasi Petani Dalam Usahatani Tanaman Gambir (Uncaria gambir roxb) di Kecamatan Sutera Kabupaten Pesisir Selatan. Agrica Ekstensia. 9 (1): 58-64. 2015

[15] Rukka, Hermaya dan Arman, Wahab. 2013. Faktor-Faktor yang Mempengaruhi Motivasi Petani dalam Pelaksanaan Kegiatan P2BN di Kecamatan Barru, Kabupaten Barru. Jurnal Agrisistem. 9 (1): 46-56. 2013

[16] Kurniati, Dewi. Analisis Risiko Usahatani Kedelai di Kecamatan Jawai Selatan Kabupaten Sambas. Manajemen MOTIVASI. 316-323. 2016 